\title{
The Impact of Enterprise Heterogeneity on the Export Choice of Automobile Enterprises
}

\author{
Yi-Hao TIAN ${ }^{1, a}$, Gao-Feng ZHU ${ }^{2, b}$ \\ School of Economics of Sichuan University, Chengdu, China \\ atyh913@126.com, bzgfbob@163.com
}

Key words: Enterprise heterogeneity, Export, Productivity.

\begin{abstract}
The new-new trade theory, which focuses on enterprise's heterogeneity, is one of the frontier theories of international trade. It shows a strong explanation of the latest international trade phenomenon. We combine the frontier theory of international trade with the realistic demand of the development of automobile enterprises in China and analyze the export choice of China's automobile enterprises. We find that both the approximate total factor productivity and the labor productivity have a significant positive impact on the China's auto companies export proportion. The high-productivity auto companies will export and continue to expand the proportion of exports, while the low-productivity auto companies will not export, or continue to reduce the proportion of exports.
\end{abstract}

\section{Introduction}

With the deep implementation of China's reform and opening up strategy, China's auto companies take actively participate in the international division of labor and globalization process through the exports, FDI and other forms. But how to choose the best international approach is still worthy of our study. The new-new trade theory is to study the international trade from the difference of micro-level enterprise labor productivity. We combine the actual situation of China's automobile industry with the new-new trade theory to study the international trade of China's auto companies. Through adding the specific variables and assumptions to the heterogeneous enterprise theory, the result of the model analysis has positive reference significance for the development of China's automobile enterprises.

\section{Literature Review}

Bernard and Jensen (1995) firstly incorporated heterogeneity of enterprises into the study of international trade theory. Through comparing the export and non-export enterprises of all US manufacturing sectors, they found that export enterprises tend to have a larger scale of production, higher labor productivity and more skilled production technology. The enterprises differences in the production scale, labor productivity and production technology show the heterogeneity of these export enterprises[1]. Melitz (2003), through empirical analysis of data from US companies, found export activities are often driven by higher-productivity enterprises in the international trade, while those companies with low productivity tend to supply only their own markets and even withdrew from the market [2]. Bernard et al. (2003) extended the Ricardian model and they found that the productivity and size of the firm affect the choice of export trade, higher productivity and larger companies choose to export, the reduction in trade barriers will promote the export of the firm[3]. Baldwin (2005) analyzed the differences in productivity between different firms based on the Melitz model and further confirmed that in the international trade companies with high productivity will choose to export[4].

\section{Theoretical Hypothesis}

What determines the export of Chinese cars and related products? According to the HMY theory[5], the difference in the productivity of enterprises determines some enterprises choose to export and 
some companies choose to sell in their own country. The automobile companies with high production efficiency, which have a certain excess profits, are most likely to choose to export. From the export capacity and the export motivation, the car companies with the high production efficiency will choose to export and continue to expand the export proportion. However, the car companies with the low production efficiency are maybe on the margins of extremely meager profit. These companies are likely to take the initiative to give up export behavior. Therefore, we have the assumption that high-productivity auto companies will export and continue to expand the proportion of exports, while the low-productivity auto companies will not export or continue to reduce the proportion of exports.

\section{Empirical Analysis}

\section{Variable Selection and Data Sources}

This paper chooses enterprises in the automobile sector of China's listed companies as a research sample. After data screening and processing of "Chinese Listed Companies Financial Statements Notes Database" from 2003 to 2010 provided by CSMAR Solution, we get 128 valid sample data due to lack of data, involving 41 listed companies in the automobile category.

We use "approximate total factor productivity" to represent the productivity of the firm, which is expressed by Griffhes and Mairesse (1990)[6], Head and Ries (2003)[7]. The formula is as follows:

$$
\mathrm{ATFP}=\ln (\mathrm{Q} / \mathrm{L})-\mathrm{s} * \ln (\mathrm{K} / \mathrm{L})
$$

$\mathrm{Q}$ is the output, we use the "total amount of income" to measure; $\mathrm{L}$ is the labor input, which is "wage payable" divided by "wage level"; $\mathrm{K}$ is the capital investment, we select "total assets" to measure; S represents the degree of contribution of capital to approximate total factor productivity. According to Hall and Jones (1999), we usually set $s=1 / 3$. In order to compensate for the possible errors when $s=1 / 3$, we can also use labor productivity as a reference to approximate total factor productivity, the calculation method is as follows:

$$
\mathrm{LTFP}=\ln (\mathrm{Q} / \mathrm{L})
$$

It is equal to approximate total factor productivity at $s=0$. The important reason for taking this indicator is that China's manufacturing industries are mainly labor-intensive industries. In labor-intensive industries, labor productivity can almost fully reflect the production efficiency of enterprises. Although the auto industry is a capital-intensive industry, the labor force in China's auto industry cannot be ignored, so labor productivity also has some reference value. Therefore, the productivity of listed companies can be more accurately reflected using two methods of calculation.

The dependent variable is the ratio of exports to total income of the listed companies, expressed as EX. The higher the ratio, the greater the export proportion of listed companies. The independent variable is the productivity, we use both ATFP and LTFP to measure, the higher the value, the higher the productivity of listed companies. The control variables set up in this paper is as follows: the total income of listed companies, which measures the size of listed companies, is expressed as Scale. The gross margin of listed companies, which measures the profitability of listed companies, is expressed as Profit. Table 1 gives a descriptive statistical result of the variables.

Table 1: Descriptive Statistical Result of the Variables

\begin{tabular}{|l|l|l|l|l|l|}
\hline Variables & Definition & Minimum & Maximum & Mean & Standard Error \\
\hline EX & $\begin{array}{l}\text { the ratio of exports to total } \\
\text { income }\end{array}$ & 0.054 & 79.685 & 18.516 & 20.263 \\
\hline ATFP & $\begin{array}{l}\text { approximate total factor } \\
\text { productivity }\end{array}$ & 2.013 & 10.707 & 7.547 & 1.842 \\
\hline LTFP & labor productivity & 6.727 & 16.292 & 12.643 & 2.053 \\
\hline InScale & $\begin{array}{l}\text { the logarithm of total income of } \\
\text { listed companies }\end{array}$ & 13.759 & 21.899 & 19.010 & 1.911 \\
\hline Profit & gross margin of listed companies & -16.654 & 49.207 & 12.930 & 10.647 \\
\hline
\end{tabular}




\section{Model}

In order to study the relationship between the productivity of listed companies and the export ratio, 128 sample data are analyzed by ordinary least squares method. The stepwise regression is used to obtain the optimal model form through adding the control variables one by one. According to the productivity calculation method (1) and (2), we set up the following eight different models for econometric analysis.

Model I: Regression analysis of approximate total factor productivity and export ratio without considering any control variables is shown in equation (3).

$$
\mathrm{EX}_{\mathrm{it}}=\alpha_{0}+\alpha_{1} \mathrm{ATFP}_{\mathrm{it}}+\varepsilon_{\mathrm{it}}
$$

Model II: Regression analysis of approximate total factor productivity and export ratio only considering the logarithm of the total income of the listed companies as a control variable is shown in equation (4).

$$
\mathrm{EX}_{\mathrm{it}}=\beta_{0}+\beta_{1} \mathrm{ATFP}_{\mathrm{it}}+\beta_{2} \operatorname{lnScale}_{\mathrm{it}}+\varepsilon_{\mathrm{it}}
$$

Model III: Regression analysis of approximate total factor productivity and export ratio only considering the gross margin of listed companies as a control variable is shown in equation (5).

$$
\mathrm{EX}_{\mathrm{it}}=\gamma_{0}+\gamma_{1} \mathrm{ATFP}_{\mathrm{it}}+\gamma_{2} \text { Profit }_{\mathrm{it}}+\varepsilon_{\mathrm{it}}
$$

Model IV: Regression analysis of approximate total factor productivity and export ratio taking into account both the logarithm of the total income and the gross margin of listed companies as control variables is shown in equation (6).

$$
\mathrm{EX}_{\mathrm{it}}=\phi_{0}+\phi_{1} \mathrm{ATFP}_{\mathrm{it}}+\phi_{2} \operatorname{lnScale}_{\mathrm{it}}+\phi_{3} \text { Profit }_{\mathrm{it}}+\varepsilon_{\mathrm{it}}
$$

Model V: Regression analysis of labor productivity and export ratio without considering any control variables is shown in equation (7).

$$
\mathrm{EX}_{\mathrm{it}}=\theta_{0}+\theta_{1} \mathrm{LTFP}_{\mathrm{it}}+\varepsilon_{\mathrm{it}}
$$

Model VI: Regression analysis of labor productivity and export ratio only considering the logarithm of the total income of the listed companies as a control variable is shown in equation (8).

$$
\mathrm{EX}_{\mathrm{it}}=\rho_{0}+\rho_{1} \mathrm{LTFP}_{\mathrm{it}}+\rho_{2} \ln \text { Scale }_{\mathrm{it}}+\varepsilon_{\mathrm{it}}
$$

Model VII: Regression analysis of labor productivity and export ratio only considering the gross margin of listed companies as a control variable is shown in equation (9).

$$
\mathrm{EX}_{\mathrm{it}}=\xi_{0}+\xi_{1} \mathrm{LTFP}_{\mathrm{it}}+\xi_{2} \text { Profit }_{\mathrm{it}}+\varepsilon_{\mathrm{it}}
$$

Model VIII: Regression analysis of labor productivity and export ratios taking into account both the logarithm of the total income and the gross margin of listed companies as control variables is shown in equation (10).

$$
\mathrm{EX}_{\mathrm{it}}=\psi_{0}+\psi_{1} \mathrm{LTFP}_{\mathrm{it}}+\psi_{2} \operatorname{lnScale}_{\mathrm{it}}+\psi_{3} \text { Profit }_{\mathrm{it}}+\varepsilon_{\mathrm{it}}
$$

In addition, if the problem of heteroskedasticity, sequence autocorrelation or multiple collinearity is encountered in the empirical process, it can be corrected and adjusted directly on these models.

\section{Empirical Regression Results}

\section{Regression analysis of Approximate Total Factor Productivity and Export Ratio}

The empirical analysis significance test results of the effect of approximate total factor productivity on the export ratio are listed in Table 2. Each of the different models shows different empirical results with different control variables. After testing, we use the mixed regression model. In the empirical process, there is obvious sequence autocorrelation in the mixed data. In order to obtain more reliable results, the generalized difference method is used to eliminate the sequence autocorrelation. 
Table 2: Empirical Regression Results

\begin{tabular}{|l|l|l|l|l|l|l|l|l|}
\hline & \multicolumn{3}{|l|}{ Model I } & \multicolumn{2}{l|}{ Model II } & \multicolumn{2}{l|}{ Model III } & \multicolumn{2}{l|}{ Model IV } \\
\cline { 2 - 9 } & coefficient & Prob. & coefficient & Prob. & coefficient & Prob. & coefficient & Prob. \\
\hline C & $-31.015^{* * *}$ & 0.000 & $-44.650^{* * *}$ & 0.005 & $-22.911^{* * *}$ & 0.001 & $-42.145^{* * *}$ & 0.037 \\
\hline ATFP & $6.555^{* * *}$ & 0.000 & $5.729^{* * *}$ & 0.000 & $5.958^{* * *}$ & 0.000 & $4.867^{* * *}$ & 0.000 \\
\hline InScale & - & - & 1.049 & 0.359 & - & - & 1.423 & 0.317 \\
\hline Profit & - & - & - & - & -0.102 & 0.384 & -0.084 & 0.480 \\
\hline AR(1) & $0.604^{* * *}$ & 0.000 & $0.595^{* * *}$ & 0.000 & 0.667 & 0.000 & $0.661^{* * *}$ & 0.000 \\
\hline Adjusted R & 0.660 & & 0.660 & & 0.702 & & 0.702 & \\
\hline F test value & 123.455 & 82.4780 & 77.187 & 58.160 & \\
\hline $\begin{array}{l}\text { D.W. test } \\
\text { value }\end{array}$ & 1.917 & 1.917 & 1.642 & & 1.634 & \\
\hline
\end{tabular}

Note: ${ }^{*}, * *, * * *$ respectively indicate that the estimated coefficients are statistically significant at $10 \%, 5 \%$ and $1 \%$ confidence levels.

It can be obtained from Table 2 that the empirical results in model I after eliminating sequence autocorrelation are the best. So the final regression equation is:

$$
\mathrm{EX}_{\mathrm{it}}=-31.015+6.555 * \mathrm{ATFP}_{\mathrm{it}}+0.604 * \mathrm{AR}(1)
$$

The test absolute value of each parameter is greater than critical value at $1 \%$ significance level. So the variable parameters are significantly not zero. The adjusted coefficient is 0.66 , indicating that the change of approximate total factor productivity can explain $66 \%$ of the change of the export ratio of enterprises. The above results show that the approximate total factor productivity has a significant positive impact on the export ratio of China's automobile enterprises. The empirical results are consistent with the previous hypothesis. High-productivity car companies will export and continue to expand the proportion of exports, while low-productivity car companies will not export or continue to reduce the proportion of exports.

\section{Regression Analysis of Labor Productivity and Export Ratio}

The empirical analysis significance test results of the effect of labor productivity on the export ratio are listed in Table 3. Each of the different models shows different empirical results with different control variables. As before, we use the mixed regression model. In the empirical process, there is obvious sequence autocorrelation in the mixed data. In order to obtain more reliable results, the generalized difference method is used to eliminate the sequence autocorrelation.

Table 3: Empirical Regression Results

\begin{tabular}{|l|l|l|l|l|l|l|l|l|}
\hline & \multicolumn{2}{|l|}{ Model V } & \multicolumn{2}{l|}{ Model VI } & \multicolumn{2}{l|}{ Model VII } & \multicolumn{2}{l|}{ Model VIII } \\
\cline { 2 - 9 } & coefficient & Prob. & coefficient & Prob. & coefficient & Prob. & coefficient & Prob. \\
\hline C & $-50.119^{* * *}$ & 0.000 & $-79.051^{* * *}$ & 0.000 & $-40.284^{* * * *}$ & 0.000 & $-73.912^{* * *}$ & 0.000 \\
\hline LTFP & $5.418^{* * *}$ & 0.000 & $3.663^{* * *}$ & 0.000 & $4.943^{* * *}$ & 0.000 & $3.066^{* * *}$ & 0.003 \\
\hline lnScale & - & - & $2.701^{* * *}$ & 0.010 & - & - & $2.969^{* *}$ & 0.019 \\
\hline Profit & - & - & - & - & -0.116 & 0.346 & -0.072 & 0.552 \\
\hline AR(1) & $0.622^{* * *}$ & 0.000 & $0.598^{* * *}$ & 0.000 & $0.680^{* * *}$ & 0.000 & $0.6641^{* * *}$ & 0.000 \\
\hline Adjusted R & 0.618 & & 0.635 & & 0.671 & & 0.687 & \\
\hline F test value & 103.008 & 74.202 & & 67.077 & & 54.271 & \\
\hline $\begin{array}{l}\text { D.W. test } \\
\text { value }\end{array}$ & 1.921 & 1.921 & & 1.635 & & 1.627 & \\
\hline
\end{tabular}

Note: *,**,*** respectively indicate that the estimated coefficients are statistically significant at $10 \%, 5 \%$ and $1 \%$ confidence levels.

It can be obtained from Table 3 that the empirical results in model I after eliminating sequence autocorrelation are the best. So the final regression equation is:

$$
\mathrm{EX}_{\mathrm{it}}=-50.119+5.418 * \mathrm{LTFP}_{\mathrm{it}}+0.622 * \mathrm{AR}(1)
$$


The $t$ test absolute value of each parameter is greater than critical value at $1 \%$ significance level. So the variable parameters are significantly not zero. The adjusted coefficient is 0.618 , indicating that the change of labor productivity can explain $61.8 \%$ of the change of the export ratio of enterprises. The above results show that the labor productivity has a significant positive impact on the export ratio of China's automobile enterprises. The empirical results are consistent with the previous hypothesis.

\section{Enlightenment}

Productivity is an important indicator of the export decision of China's automobile enterprises. Internationalization is the trend of economic development. Entering the internationalization can find new profit growth point and improve the overall economic efficiency. However, not all companies are suitable for entering the international market. Automobile enterprises cannot export blindly except that it has grown to a certain extent where the firm has the production capacity, fully understand foreign market demand, can control the relevant risks of export. Or internationalization will lead to the improve cost because of export without the improvement of economic efficiency and profit, eventually leading to corporate losses or even bankruptcy. Obviously, the export decision-making is closely related to the labor productivity and the total factor productivity of the enterprises. On the whole, the factors of productivity are very important for the survival of the automobile enterprises. In the short term, the automobile enterprises should pay attention to the productivity of the enterprises. If the labor productivity is improved, then the enterprises' exports will have a strong support.

In supporting the development of China's automobile industry, the government should focus on promoting the merger and reorganization of the domestic automobile industry to enhance the economies of scale. At present, China's auto export market are concentrated in the developing countries, China has so many auto exporters whose cars lack of differences, most of the exports are carrying out the homogenization of the price competition. These status quo has a serious impact on the export efficiency of auto companies. According to judgment of the international industry monopoly and competition, the automotive industry is highly oligopoly industry. In the developed countries, the concentration of auto market is very high, the top three companies accounted for $90 \%$ in America, $80 \%$ in Japan, 100\% in France and Italy, but the top ten car companies production only accounted for $87 \%$ in China, the remaining car manufacturer accounted for less than $20 \%$. Because industry production concentration is too low to lead to scale economy, the enterprise's total factor productivity is not high. Meanwhile other problems such as low-quality products, after-sales service damage the image of Chinese auto exporters. So Chinese government should adopt a proactive policy to encourage mergers and acquisitions among auto enterprises, which can enhance economies of scale, improve the strength of enterprises, and ultimately achieve increased productivity.

\section{References}

[1]Bernard, Andrew B.; Jensen, J. Bradford. Exporters, Jobs, and Wages in the U.S. Manufacturing: 1976-1987 Brookings Papers on Economic Activity[J]. Special Issue Microeconomics: 67-119.

[2]Melitz, Marc J. The Impact of Trade on Intra-Industry Reallocations and Aggregate Industry Productivity[J]. Econometrica, Vol. 71, No.6, 2003:1695-1725.

[3]Bernard, Andrew B., Eaton, J., Jensen, J.B and Kortum, S. Plants and Productivity in International Trade[J]. American Economic Review, Vol.93, No.4, 2003:1268-1292.

[4]Baldwin, R.E. and Okubo, T. Agglomeration and the Heterogeneous Firms Trade Model[A]. Working Paper, 2005/9--Heterogeneous Firms, Agglomeration and Economic Geography: Spatial Selection and Sorting [J]. Journal of Economic Geography, Vol. 6, 2006b: 323-346.

[5]Ghironi, F., Melitz, M. J. International Trade and Macroeconomic Dynamics with Heterogeneous 
Firms[J]. The Quarterly Journal of Economics, 2005(3): 865-915.

[6]Helpman, E, Melitz, Marc J and Yeaple, S.R. Export Versus FDI with Heterogeneous Firms[J]. The American Economic Review, Vol. 94, No.1, 2004: 300-316.

[7]Griliehes, Z. and Mairesse, J. R\&D and Productivity growth: comparing Japan and US manufacturing firms. [M]. In: Hulten, C., Productivity Growth in Japan and the United States. The University of Chicago Press, 1990, Chicago.

[8]Head, K. and Ries, J. Heterogeneity and the FDI versus export decision of Japanese manufacturers[J]. Japanese Int. Economies, 2003(17): 448-467. 